\title{
Purine analogue ENERGI-F706 induces apoptosis of 786-O renal carcinoma cells via 5 '-adenosine monophosphate-activated protein kinase activation
}

\author{
CHAO-YU HSU ${ }^{1}$, CHUN-HSIANG LIN ${ }^{2}$, JIUN-TSAI LIN ${ }^{3}$, \\ YI-FANG CHENG $^{4}$, HAN-MIN CHEN ${ }^{3-5}$ and SHAO-HSUAN KAO ${ }^{2,6}$
}

\author{
${ }^{1}$ Division of Urology, Department of Surgery, Tungs' Taichung Metro Harbor Hospital, Taichung 435; \\ ${ }^{2}$ Institute of Biochemistry and Biotechnology, College of Medicine, Chung Shan Medical University, Taichung 402; \\ ${ }^{3}$ Institute of Applied Science and Engineering, Catholic Fu-Jen University, New Taipei 242; \\ ${ }^{4}$ Energenesis Biomedical Co. Ltd., New Taipei 235; ${ }^{5}$ Department of Life Science, Catholic Fu-Jen University, \\ New Taipei 242; ${ }^{6}$ Clinical Laboratory, Chung Shan Medical University Hospital, Taichung 402, Taiwan, R.O.C.
}

Received August 24, 2014; Accepted May 1, 2015

DOI: $10.3892 / \mathrm{mmr} .2015 .3906$

\begin{abstract}
Purine compounds are known to activate 5 '-adenosine monophosphate-activated protein kinase (AMPK), which has important roles in treatments for renal cell carcinoma. The present study was aimed to investigate the effects of the purine analogue ENERGI-F706 on the human renal carcinoma cell line 786-O and the underlying mechanisms. The results revealed that ENERGI-F706 $(0.2-0.6 \mathrm{mg} / \mathrm{ml})$ significantly decreased the cell viability to up to $36.4 \pm 2.4 \%$ of that of the control. Compared to $786-\mathrm{O}$ cells, ENERGI-F706 exerted less suppressive effects on the viability of the human non-tumorigenic renal cell line HK-2. Flow cytometric analysis showed that ENERGI-F706 contributed to cell cycle arrest at S-phase and triggered apoptosis of 786-O cells. Immunoblot analysis revealed that anti-apoptotic B-cell lymphoma 2 (Bcl-2) levels were reduced and pro-apoptotic Bcl-2-associated $\mathrm{X}$ protein levels were diminished. In addition, activation of caspase-9, caspase-3 and poly(adenosine diphosphate ribose) polymerase (PARP) was promoted in 786-O cells in response to ENERGI-F706. Effects of ENERGI-F706 on AMPK cascades were investigated and the results showed that ENERGI-F706 enhanced phosphorylation of AMPK $\alpha$ (T172) and p53 (S15), a downstream target of AMPK. In addition, the AMPK activation, p53 (S15) phosphorylation, reduction of Bcl-2, cleavage of
\end{abstract}

Correspondence to: Professor Shao-Hsuan Kao, Institute of Biochemistry and Biotechnology, College of Medicine, Chung Shan Medical University, 110 Sec. 1, Jianguo N. Road, Taichung 402, Taiwan, R.O.C.

E-mail:kaosh@csmu.edu.tw

Key words: apoptosis, 5'-adenosine monophosphate-activated protein kinase, B-cell lymphoma 2, B-cell lymphoma-2-associated X, ENERGI-F706, caspase, renal cell carcinoma 786-O caspase-3 and PARP as well as suppressed cell viability induced by ENERGI-F706 were reversed in the presence of AMPK inhibitor compound C (dorsomorphin). In conclusion, the findings of the present study revealed that ENERGI-F706 significantly suppressed the viability of 786-O cells via induction of cell cycle arrest and apoptosis, attributing to AMPK and p53 activation and subsequent cell cycle regulatory and apoptotic signaling. It was therefore indicated that ENERGI-F706 may be suitable for the treatment of renal cell carcinoma.

\section{Introduction}

Renal cell carcinoma (RCC) is the third most prevalent urological malignancy, accounting for $85 \%$ of kidney cancer in adults. Based on pathological properties, RCC can be classified into three major types, including clear cell carcinoma (70-80\%), papillary carcinoma (10-15\%) and chromophobe RCC ( 5\%) (1). RCC cells are highly proliferative and metastatic, and account for $3.8 \%$ of all cancers in adults (2). Surgical intervention, including radical nephrectomy and nephron-sparing surgery is the primary treatment for RCC; however, the surgical treatments are not optimal for RCC patients who develop metastases or recurring disease. Furthermore, the vast majority of RCCs eventually become resistant to conventional treatments and the recently approved targeted therapy (3). Thus, the development of novel treatment strategies for RCC is required.

Accumulating evidence has shown that dysregulation of cellular energy sensing is associated with carcinogenesis, including the genesis of RCC (4). 5'-Adenosine monophosphate-activated protein kinase (AMPK) is an important sensor for cellular energy levels in all eukaryotes. AMPK is activated under conditions of low intracellular adenosine triphosphate, attributing to nutrient deprivation and hypoxia (5). Previous studies have shown that AMPK governs important cellular physiology, including cell proliferation, cell growth and autophagy $(6,7)$. AMPK activation 
has been reported to inhibit growth of various carcinoma cell lines, including HepG2 (liver cancer) and SW620 (colorectal cancer) $(8,9)$. Previous studies have reported that genetic manipulation of the AMPK-upstream activator liver kinase B1 is crucial for hepatoma development (10) and that activated AMPK inhibits hepatoma growth by destabilizing p53 in a sirtuin 1-dependent manner (11). These findings provided evidence that AMPK may serve as a potential anti-tumor target for treating various carcinoma types.

The present study aimed to investigate the anti-tumoral activity of ENERGI-F706 (CAS number 73-24-5), a purine analogue purified from Phyllostachys edulis, on human $\mathrm{RCC}$, as well as the underlying mechanism. Cell viability and cell cycle distribution were determined using an MTT assay and flow cytometric analysis, respectively. Phosphorylation and protein levels were assessed by immunoblot analysis. Furthermore, the involvement of AMPK signaling was demonstrated using a specific inhibitor.

\section{Materials and methods}

Chemicals and reagents. All reagents were purchased from Sigma-Aldrich (St Louis, MO, USA) unless specified otherwise. RPMI-1640 and fetal bovine serum (FBS) were purchased from Invitrogen Life Technologies (Carlsbad, CA, USA). ENERGI-F706 was a proprietary compound generously provided by Energenesis-Biomedical Co., Ltd. (New Taipei, Taiwan). Antibodies against caspase-3 (cat. no. 9668), caspase-8 (cat. no. 9496), caspase-9 (cat. no. 2876), B-cell lymphoma 2 (Bcl-2; cat. no. 2876), Bcl-2-associated X protein (Bax; cat. no. 2774), phospho-(p-) AMPK (T172) (cat. no. 2531), AMPK (cat. no. 2532), p-p53 (S15) (cat. no. 9286), p53 (cat. no. 9282) and poly(adenosine diphosphate ribose) polymerase (PARP; cat. no. 9541) were purchased from Cell Signaling Technologies (Danvers, MA, USA). Antibodies against GAPDH (cat. no. G8795) were obtained from Sigma-Aldrich. Horseradish peroxidase (HRP)-conjugated secondary antibodies against mouse immunoglobulin (Ig)G (cat. no. ab6789) and rabbit IgG (cat. no. ab97051) were purchased from Abcam Inc. (Cambridge, UK).

Cell culture and experimental treatments. The human RCC cell line 786-O (ATCC ${ }^{\circledR}$ CRL-1932 ${ }^{\mathrm{TM}}$ ) and HK-2 human renal cell line (ATCC ${ }^{\circledR}$ CRL-2190 ${ }^{\mathrm{TM}}$ ) was obtained from the American Type Culture Collection (Manassas, VA, USA) and maintained in RPMI-1640 with $10 \% \mathrm{FBS}$ at $37^{\circ} \mathrm{C}$ in a humidified atmosphere containing $5 \% \mathrm{CO}_{2}$. Cells were trypsinized upon confluency and propagated to passage two prior to being sub-cultured into six-well plates for further treatments.

For treatments, cells were seeded in six-well culture plates at an initial density of $1 \times 10^{5}$ cells $/ \mathrm{ml}$ and grown to $80 \%$ confluence. All treatments were performed using serum-free RPMI-1640. For cell viability and cell cycle distribution, the cells were treated with ENERGI-F706 (0.05, 0.1, 0.2, 0.4 and $0.6 \mathrm{mg} / \mathrm{ml}$ ) for $24 \mathrm{~h}$. To determine the involvement of AMPK in the suppression of cell viability, the cells were pre-incubated with or without $5 \mu \mathrm{M}$ compound C (Sigma-Aldrich) for $4 \mathrm{~h}$, and then treated with ENERGI-F706 (0.05, 0.1, 0.2,

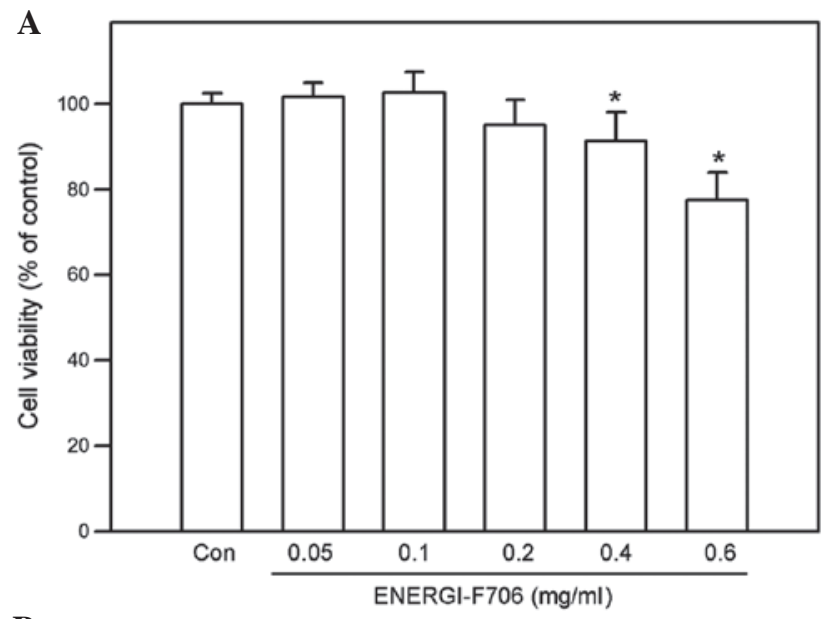

B

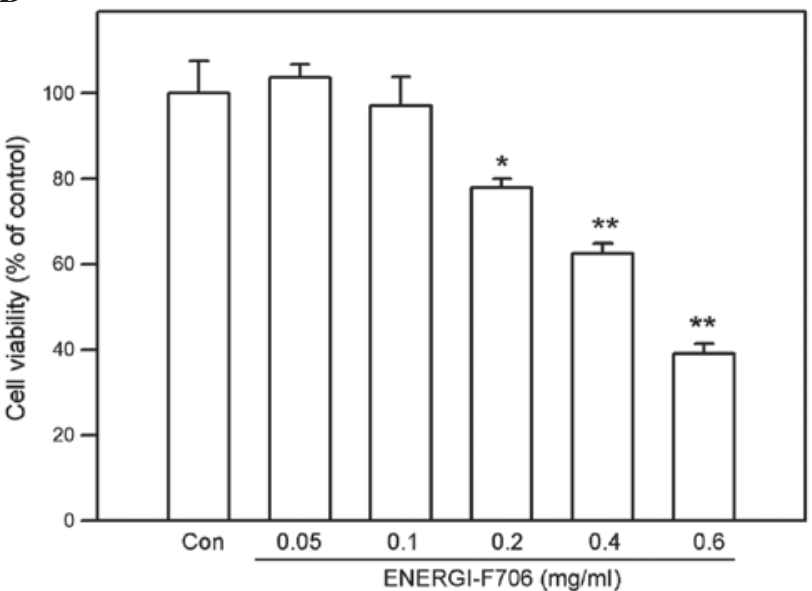

Figure 1. Effects of ENERGI-F706 on viability of renal cells. (A) HK-2 cells and (B) 786-O cells were treated with ENERGI-F706 at the indicated concentrations for $24 \mathrm{~h}$ and then subjected to a cell viability assay. Values are expressed as the mean \pm standard error of the mean for three independent experiments. ${ }^{*} \mathrm{P}<0.01{ }^{* *} \mathrm{P}<0.005$ vs. Con. Con, control.

0.4 and $0.6 \mathrm{mg} / \mathrm{ml}$ ) for $24 \mathrm{~h}$. After the treatments, the cells were washed with phosphate-buffered saline (PBS; $25 \mathrm{mM}$ sodium phosphate; $150 \mathrm{mM} \mathrm{NaCl}$; $\mathrm{pH}$ 7.2) and collected for the subsequent analyses.

Cell viability assay. Cell viability was determined using the MTT assay (12) in the absence or presence of ENERGI-F706. After 24- or 48-h treatments, the culture medium was aspirated and cells were incubated with MTT $(0.5 \mathrm{mg} / \mathrm{ml})$ at $37^{\circ} \mathrm{C}$ for $4 \mathrm{~h}$. The viable cell number was directly proportional to the production of formazan, which was dissolved in isopropanol and determined by measuring the absorbance at $570 \mathrm{~nm}$ using a microplate reader (SpectraMAX $360 \mathrm{pc}$; Molecular Devices, Sunnyvale, CA, USA).

Cell cycle distribution analysis. Cells were synchronized at $\mathrm{G}_{0}$ phase by serum starvation for $16 \mathrm{~h}$ and then incubated in fresh serum-containing medium to allow for cell-cycle progression. At various time-points after release from $\mathrm{G}_{0}$ arrest, cells were analyzed by flow cytometry to determine the cell cycle distribution. At the end of the treatment, cells were collected, fixed with $1 \mathrm{ml}$ ice-cold $70 \%$ ethanol, incubated at $-20^{\circ} \mathrm{C}$ for $24 \mathrm{~h}$ and centrifuged at $380 \mathrm{xg}$ for $5 \mathrm{~min}$ at room temperature. Cell 

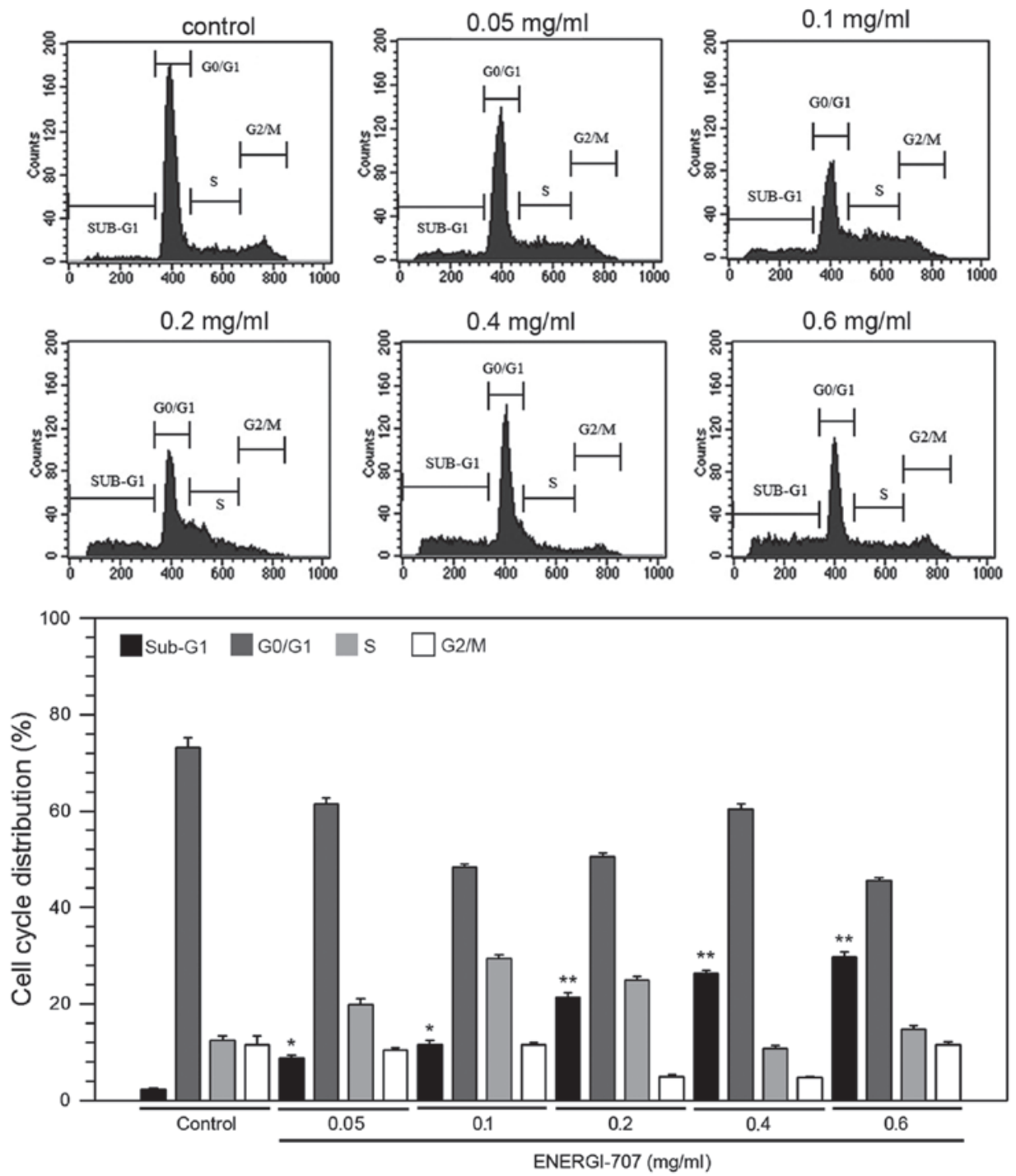

Figure 2. Effects of ENERGI-F706 on the cell cycle distribution of 786-O cell. Cells were treated with ENERGI-F706 at the indicated concentrations for $24 \mathrm{~h}$ and then subjected to flow cytometric analysis for determining the cell cycle distribution. Each cell cycle phase population is presented as a percentage. Values are expressed as the mean \pm standard error of the mean for three independent experiments. ${ }^{*} \mathrm{P}<0.05 ;{ }^{* *} \mathrm{P}<0.01$ vs. control.

pellets were treated with $1 \mathrm{ml}$ cold staining solution containing $20 \mu \mathrm{g} / \mathrm{ml}$ propidium iodide (PI), $20 \mu \mathrm{g} / \mathrm{ml}$ RNase A and $1 \%$ Triton X-100, and incubated for $15 \mathrm{~min}$ in the dark at room temperature. Subsequently, the samples were analyzed in a FACS Calibur system (BD Biosciences, Franklin Lakes, NJ, USA) using CellQuest version 2.0 software. Representative results were acquired from three independent experiments.

Immunoblot analysis. Cells were washed with PBS and then lysed with lysis buffer $(50 \mathrm{mM}$ Tris- $\mathrm{HCl}, \mathrm{pH} 7.5,1 \%$ Nonidet $\mathrm{P}-40,1 \mathrm{mM}$ phenylmethylsulfonyl fluoride and $1 \mathrm{mM} \mathrm{NaF}$ ) containing complete protease inhibitor cocktail (Roche Diagnostics, Basel, Switzerland). The crude extracts were collected and protein contents were quantitated using the bicinchoninic acid (BCA) method. Crude proteins (20 $\mu \mathrm{g}$ per lane) were subjected to $12.5 \%$ SDS-PAGE and then transferred onto a nitrocellulose membrane (Millipore, Billerica, MA, USA). After blocking with 5\% w/v skimmed milk/PBS, the membrane was incubated with optimal diluted first antibodies $(1: 1,000)$ for $2 \mathrm{~h}$ at room temperature, and then with
HRP-conjugated secondary antibodies $(1: 2,000)$ for $1 \mathrm{~h}$ at room temperature. Development was performed using an enhanced chemiluminescence reagent (Millipore). The luminescent signal was acquired and quantitated using the LAS-4000 image analysis system with LAS-4000mini analysis software (Fuji Film, Tokyo, Japan).

Statistical analysis. Values are expressed as the mean \pm standard error of the mean of the three independent experiments. Statistical significance was determined by using one-way analysis of variance followed by Dunnett's test for multiple comparisons with the control. Statistical analysis was conducted using SigmaStat version 3.5 (Systat Software, Inc., San Jose, CA, USA). P $<0.05$ was considered to indicate a statistically significant difference between values.

\section{Results}

Effects of ENERGI-F706 on the viability of 786-O and $\mathrm{HK}-2$ cells. Changes in cell viability in response to ENERGI-F706 
were determined using an MTT assay. As shown in Fig. 1A, the viability of HK-2 cells was reduced to $90.1 \pm 7.2$ and $79.6 \pm 6.9 \%$ of the control following treatment with 0.4 and $0.6 \mathrm{mg} / \mathrm{ml}$ ENERGI-F706, respectively $(\mathrm{P}<0.05)$. In addition, the viability of $786-\mathrm{O}$ cells was reduced to $76.3 \pm 3.9,62.4 \pm 4.2$ and $36.4 \pm 2.4 \%$ of that of the control following treatment with $0.2,0.4$ and $0.6 \mathrm{mg} / \mathrm{ml}$ ENERGI-F706, respectively $(\mathrm{P}<0.05)$ (Fig. 1B). These findings demonstrated that ENERGI-F706 treatment $(>0.2 \mathrm{mg} / \mathrm{ml})$ significantly inhibited the viability of $786-\mathrm{O}$ cells.

ENERGI-F706 induces cell cycle arrest and apoptosis of 786-O cells. To explore the effects of ENERGI-F706 on the cell cycle and apoptosis of 786-O cells, they were assessed using flow cytometric assays. As shown in Fig. 2, 24-h ENERGI-F706 treatment increased the sub- $\mathrm{G}_{1}$-phase population in a dose-dependent manner by up to $28.6 \pm 1.7 \%(0.6 \mathrm{mg} / \mathrm{ml} ; \mathrm{P}<0.01$ vs. control). In addition, the $\mathrm{S}$-phase population was also increased in response to ENERGI-F706 at low doses $(0.05,0.1$ and $0.2 \mathrm{mg} / \mathrm{ml}$; $\mathrm{P}<0.05$ as compared to control). By contrast, the $\mathrm{G}_{0} / \mathrm{G}_{1}$-phase population was decreased in response to ENERGI-F706 treatment $(0.05-0.6 \mathrm{mg} / \mathrm{ml} ; \mathrm{P}<0.05$ as compared to control). Collectively, these results demonstrated that ENERGI-F706 treatment remarkably altered the cell cycle distribution of 786-O cells and induced apoptosis.

ENERGI-F706 initiates apoptotic signaling cascades in 786-O cells. To further investigate the apoptosis induced by ENERGI-F706, apoptotic cascades were examined. As shown in Fig. 3, the levels of anti-apoptotic Bcl-2 were dose-dependently decreased in 786-O cells exposed to ENERGI-F706. By contrast, levels of apoptotic proteins, including Bax, cleaved caspase-9 (35 kDa), cleaved caspase-3 (17 kDa) and cleaved PARP ( $89 \mathrm{kDa}$ ) were significantly elevated in 786-O cells treated with ENERGI-F706. These findings showed that ENERGI-F706 triggered activation of caspase cascades, including suppression of anti-apoptotic Bcl-2 and enhancement of apoptotic signaling cascades.

ENERGI-F706 induces phosphorylation of AMPKa, contributing to activation of p53 and apoptotic signaling cascades in 786-O cells. A previous study has reported that ENERGI-F704, another purine analogue similar to ENERGI-F706, possesses anti-inflammatory activity, which was attributed to the activation of AMPK signaling and subsequent inhibition of nuclear factor- $\kappa \mathrm{B}$ signaling in vascular endothelial cells (13). Accordingly, the effects of ENERGI-F706 on AMPK and the associated signaling were investigated in the present study. After $24 \mathrm{~h}$ of treatment, ENERGI-F706 enhanced the phosphorylation of AMPK $\alpha$ (T172) and p53 (S15) (Fig. 4A).

The involvement of AMPK (T172) phosphorylation in ENERGI-F706-induced p53 (S15) phosphorylation and apoptotic signaling cascades was subsequently examined. The results revealed that AMPK (T172) phosphorylation induced by ENERGI-F706 was inhibited by pre-treatment with AMPK inhibitor compound C (dorsomorphin). In parallel to inhibition of AMPK (T172) phosphorylation, p53 (S15) phosphorylation and cleavage of caspase-9 as well as

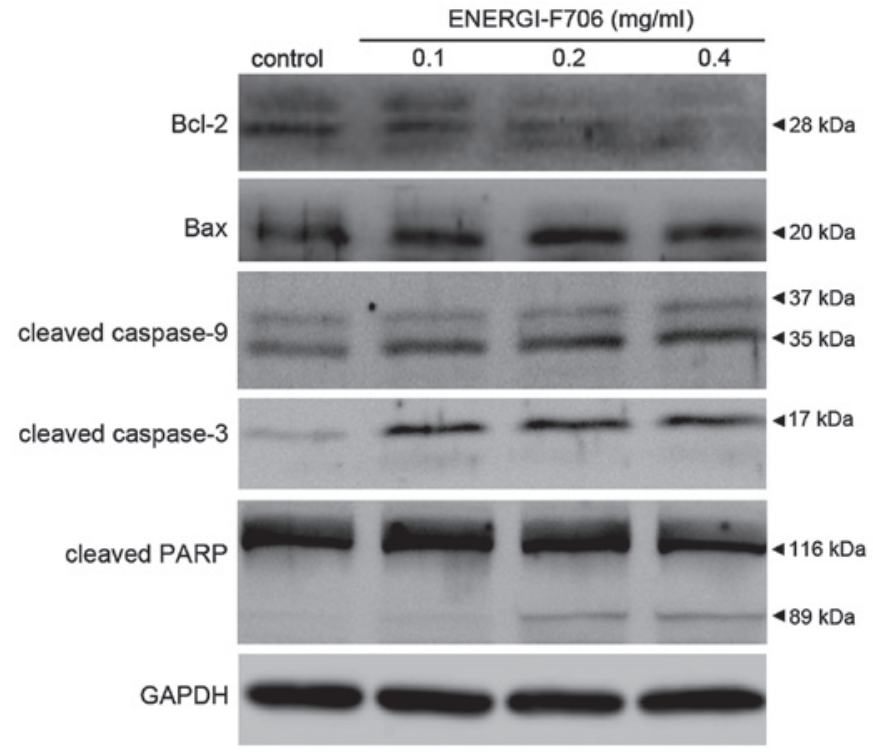

Figure 3. ENERGI-F706 regulates apoptotic proteins and induces activation of caspases. Cells were treated with $0.1,0.2$ and $0.4 \mathrm{mg} / \mathrm{ml}$ ENERGI-F706 for $24 \mathrm{~h}$, and then were lyzed for the determination of the indicated protein levels by immunoblotting. GAPDH was used as an internal control. The apparent molecular weights for detected proteins are indicated. Bcl-2, B-cell lymphoma 2; Bax, Bcl-2-associated X; PARP, poly(adenosine diphosphate ribose) polymerase.

PARP induced by ENERGI-F706 were also diminished by pre-treatment with compound C (Fig. 4B). In contrast to the apoptotic signals, the levels of anti-apoptotic Bcl-2 was restored by pre-treatment with compound $\mathrm{C}$ as compared to those following treatment with ENERGI-F706 alone (Fig. 4B). Collectively, these findings revealed that ENERGI-F706 activated AMPK and consequently triggered apoptotic signaling cascades in 786-O cells.

ENERGI-F706 decreases the viability of 786-O cells via AMPK activation. The involvement of AMPK activation in the suppression of cell viability in response to ENERGI-F706 was next investigated. As shown in Fig. 5, treatment with ENERGI-F706 alone at $0.2,0.4$ and $0.6 \mathrm{mg} / \mathrm{ml}$ for $24 \mathrm{~h}$ decreased the cell viability to $67.3 \pm 4.2,55.2 \pm 3.4$, and $40.8 \pm 4.7 \%$ of that of the control, respectively $(\mathrm{P}<0.05$ as compared to control). By contrast, after pre-treatment with $5 \mathrm{mM}$ compound $\mathrm{C}$ for $2 \mathrm{~h}$ followed by treatment with ENERGI-F706 at $0.2,0.4$ and $0.6 \mathrm{mg} / \mathrm{ml}$ for $24 \mathrm{~h}$, the cell viability was restored to $72.9 \pm 5.9,67.1 \pm 3.1$, and $53.8 \pm 2.3 \%$ of that of the control, respectively $(\mathrm{P}<0.05$ as compared to ENERGI-F706 alone). These results revealed that AMPK activation has an important role in the suppression of 786-O cell viability in response to ENERGI-F706.

\section{Discussion}

AMPK signaling has been shown to exhibit potent anti-tumor activity; thus, identifying novel AMPK activators is beneficial for developing potential anti-cancer agents $(9,14)$. Recent studies have demonstrated that AMPK activators, including AICAR and metformin, inhibit various types of malignancy, including pancreatic cancer, bladder cancer and prostate 

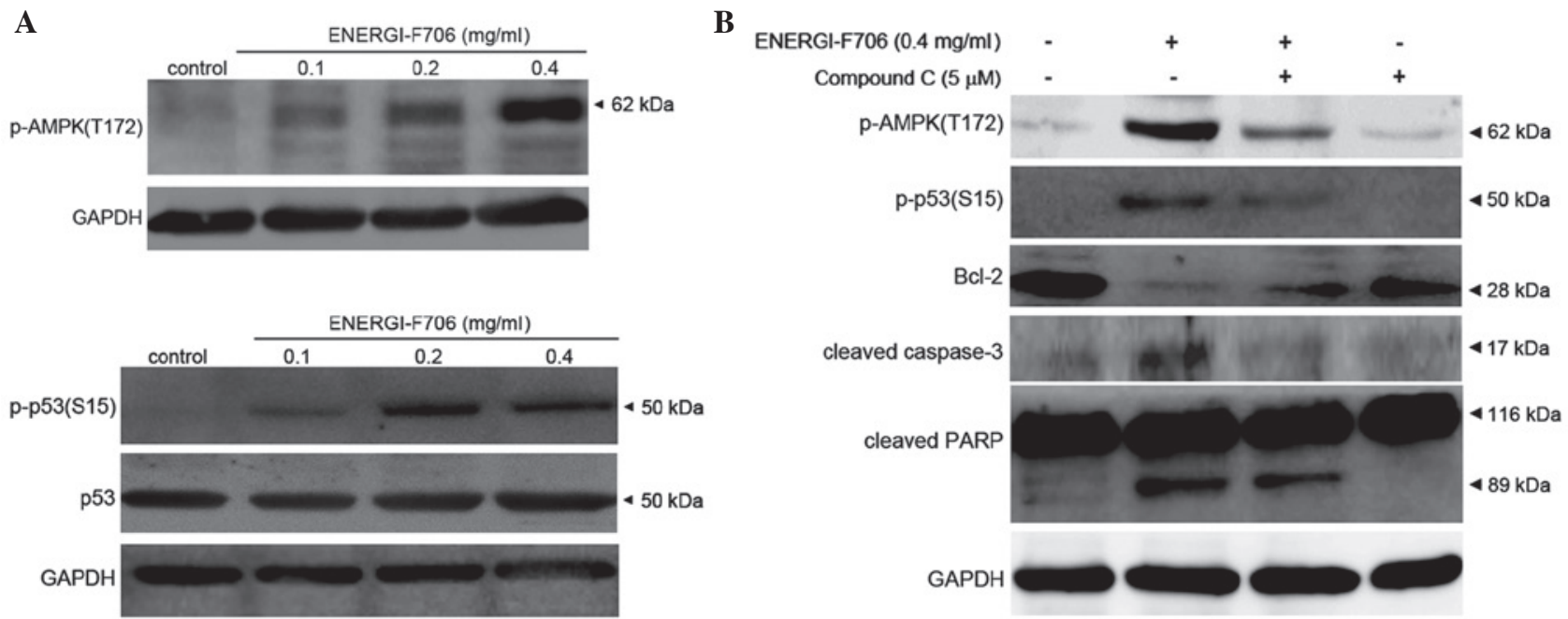

Figure 4. ENERGI-F706 induces activation of AMPK and p53 to activate apoptotic cascades. (A) Cells were treated with 0.1,0.2 and $0.4 \mathrm{mg} / \mathrm{ml}$ ENERGI-F706 for $24 \mathrm{~h}$, and then lyzed for the determination of levels of indicated proteins by immunoblotting. (B) Cells were treated with $0.4 \mathrm{mg} / \mathrm{ml}$ ENERGI-F706 and the AMPK inhibitor compound $\mathrm{C}$, followed by determination of apoptosis-associated proteins. GAPDH was used as an internal control. The apparent molecular weights of the detected proteins are indicated. p-AMPK, phospho-5'-adenosine monophosphate-activated protein kinase; Bcl-2, B-cell lymphoma 2; PARP, poly(adenosine diphosphate ribose) polymerase; compound C, AMPK inhibitor dorsomorphin.

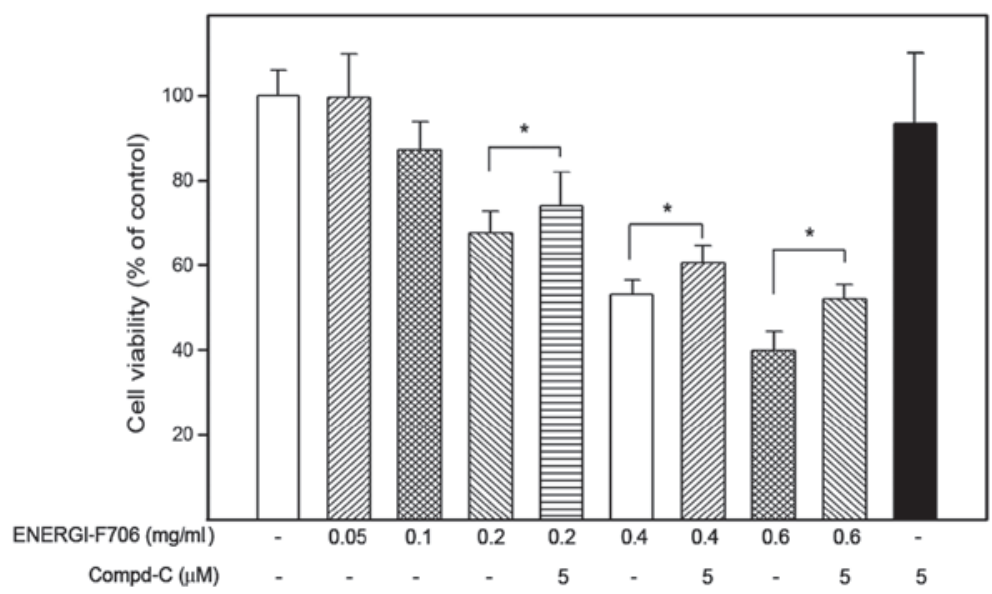

Figure 5. AMPK activation is involved in the suppression of the viability of 786-O cells in response to ENERGI-F706 treatment. Cells were treated with ENERGI-F706 alone or ENERGI-F706 combined with compound C $(5 \mu \mathrm{M})$ for $24 \mathrm{~h}$, and the cells were subjected to a cell viability assay. Values are expressed as the mean \pm standard error of the mean for three independent experiments. "P< $<.05$ vs. negative control. Compound C, AMPK inhibitor dorsomorphin.

cancer via AMPK-dependent apoptosis (15-17). Recently, Hadad et al (18) have reported that metformin significantly inhibit cell growth and cause G1 cell cycle arrest in MCF-7 and MDA-MB-231 cells (18). Similarly, the present study provided evidence that the purine compound ENERGI-F706 decreases the viability of the RCC cell line 786-O through AMPK activation and subsequent p53 activation, cell cycle arrest in S-phase and apoptosis. These findings suggested that AMPK activators possess potent anti-tumoral activity by triggering various signaling cascades to diminish cell growth and contribute to cell death.

Abnormal cells, including mutated or proliferating neoplastic cells, are eliminated through apoptosis, a programmed cell death (19). The apoptotic cell death pathway is mediated by the $\mathrm{Bcl}-2$ protein family, a group of anti-apoptotic proteins that regulate the passage of cytochrome $\mathrm{C}$, which binds to apoptotic protease activating factor 1 to form active apoptosome, which then activates caspase cascades $(20,21)$. Activated caspase-3 functions as the key executioner of apoptosis to induce the cleavage and inactivation of key cellular proteins, such as PARP $(22,23)$. The findings of the present study revealed that ENERGI-F706 reduced Bcl-2 and increased Bax levels, which promoted the cleavage of caspase-9, caspase-3 and PARP, suggesting that ENERGI-F706 enhanced pro-apoptotic mitochondrial signals and contributed to apoptosis of 786-O cells. AMPK is known to be involved in the phosphorylation of p53 on S15 to stabilize this molecule (24). In consistency with this, the results of the present study revealed that ENERGI-F706 triggered the phosphorylation of p53 (S15) in a AMPK-dependent manner, which may have contributed to a block of the cell cycle at the G2/M checkpoint and the resulting S-phase arrest (25). These findings indicated that ENERGI-F706 possesses potent anti-tumoral activity against the human RCC cell line 
786-O, which is attributed to its ability to induce cell cycle arrest as well as apoptosis.

In conclusion, the present study provided evidence that ENERGI-F706 treatment significantly suppressed the viability of the RCC cell line 786-O through activation of AMPK and a synergy of induction of apoptotic signaling and suppression of anti-apoptotic signaling. By regulating the two arms of apoptotic and anti-apoptotic signaling, ENERGI-F706 may represent a promisingly effective anti-tumor agent for the treatment of human RCC.

\section{Acknowledgements}

The present study was partly supported by the Intercollege grant (no. CSMU-TTM-102-03) from the Tungs' Taichung Metro Harbor Hospital (Taichung, Taiwan).

\section{References}

1. Prasad SR, Humphrey PA, Catena JR, Narra VR, Srigley JR, Cortez AD, Dalrymple NC and Chintapalli KN: Common and uncommon histologic subtypes of renal cell carcinoma: Imaging spectrum with pathologic correlation. Radiographics 26 1795-1806, discussion 1806-1810, 2006.

2. Jemal A, Siegel R, Xu J and Ward E: Cancer statistics, 2010. CA Cancer J Clin 60: 277-300, 2010.

3. Rini BI and Atkins MB: Resistance to targeted therapy in renal-cell carcinoma. Lancet Oncol 10: 992-1000, 2009

4. Linehan WM, Srinivasan R and Schmidt LS: The genetic basis of kidney cancer: A metabolic disease. Nat Rev Urol 7: 277-285, 2010.

5. Kahn BB, Alquier T, Carling D and Hardie DG: AMP-activated protein kinase: Ancient energy gauge provides clues to modern understanding of metabolism. Cell Metab 1: 15-25, 2005.

6. Luo Z, Saha AK, Xiang X and Ruderman NB: AMPK, the metabolic syndrome and cancer. Trends Pharmacol Sci 26 69-76, 2005

7. Hoyer-Hansen M and Jäättelä M: AMP-activated protein kinase: a universal regulator of autophagy? Autophagy 3: 381-383, 2007.

8. Imamura K, Ogura T, Kishimoto A, Kaminishi $M$ and Esumi H: Cell cycle regulation via p53 phosphorylation by a 5'-AMP activated protein kinase activator, 5-aminoimidazole4-carboxamide-1-beta-D-ribofuranoside, in a human hepatocellular carcinoma cell line. Biochem Biophys Res Commun 287: 562-567, 2001.

9. Cho SY, Lee HJ, Lee HJ, Jung DB, Kim H, Sohn EJ, Kim B, Jung JH, Kwon BM and Kim SH: Activation of amp-activated protein kinase $\alpha$ and extracelluar signal-regulated kinase mediates CB-PIC-induced apoptosis in hypoxic sw620 colorectal cancer cells. Evid Based Complement Alternat Med 2013: 974313, 2013.
10. Kim CJ, Cho YG, Park JY, Kim TY, Lee JH, Kim HS, Lee JW, Song YH, Nam SW, Lee SH, et al: Genetic analysis of the LKB1/STK11 gene in hepatocellular carcinomas. Eur J Cancer 40: 136-141, 2004.

11. Lee CW, Wong LL, Tse EY, Liu HF, Leong VY, Lee JM, Hardie DG, Ng IO, Ching YP: AMPK promotes p53 acetylation via phosphorylation and inactivation of SIRT1 in liver cancer cells. Cancer Res 72: 4394-4404, 2012.

12. Denizot F and Lang R: Rapid colorimetric assay for cell growth and survival. Modifications to the tetrazolium dye procedure giving improved sensitivity and reliability. J Immunol Methods 89: 271-277, 1986.

13. Chen HM, Lin JTK CY and Huang CF: The Effects of Novel AMPK Activator on Human Vascular Endothelial Cells. J Med Bioeng 3: 5, 2014

14. Youn SH, Lee JS, Lee MS, Cha EY, Thuong PT, Kim JR and Chang ES: Anticancer properties of pomolic acid-induced AMP-activated protein kinase activation in MCF7 human breast cancer cells. Biol Pharm Bull 35: 105-110, 2012.

15. Karnevi E, Said K, Andersson $\mathrm{R}$ and Rosendahl AH: Metformin-mediated growth inhibition involves suppression of the IGF-I receptor signalling pathway in human pancreatic cancer cells. BMC Cancer 13: 235, 2013

16. Zheng QY, Jin FS, Yao C, Zhang T, Zhang GH and Ai X: Ursolic acid-induced AMP-activated protein kinase (AMPK) activation contributes to growth inhibition and apoptosis in human bladder cancer T24 cells. Biochem Biophys Res Commun 419: 741-747, 2012.

17. Sauer H, Engel S, Milosevic N, Sharifpanah F and Wartenberg M: Activation of AMP-kinase by AICAR induces apoptosis of DU-145 prostate cancer cells through generation of reactive oxygen species and activation of c-Jun N-terminal kinase. Int J Oncol 40: 501-508, 2012.

18. Hadad SM, Hardie DG, Appleyard V and Thompson AM: Effects of metformin on breast cancer cell proliferation, the AMPK pathway and the cell cycle. Clin Transl Oncol 16: 746-752, 2014.

19. Hickman JA: Apoptosis induced by anticancer drugs. Cancer Metastasis Rev 11: 121-139, 1992.

20. Wolf BB and Green DR: Suicidal tendencies: apoptotic cell death by caspase family proteinases. J Biol Chem 274: 20049-20052, 1999.

21. Slee EA, Harte MT, Kluck RM, Wolf BB, Casiano CA, Newmeyer DD, Wang HG, Reed JC, Nicholson DW, Alnemri ES, et al: Ordering the cytochrome c-initiated caspase cascade: Hierarchical activation of caspases-2, $-3,-6,-7,-8$ and -10 in a caspase-9-dependent manner. J Cell Biol 144: 281-292, 1999.

22. Thornberry NA: Caspases: Key mediators of apoptosis. Chem Biol 5: R97-103, 1998

23. Charalambous C, Pitta CA and Constantinou AI: Equol enhances tamoxifen's anti-tumor activity by induction of caspase-mediated apoptosis in MCF-7 breast cancer cells. BMC Cancer 13: 238 , 2013.

24. Jones RG, Plas DR, Kubek S, et al: AMP-activated protein kinase induces a p53-dependent metabolic checkpoint. Mol Cell 18: 283-293, 2005.

25. Vazquez-Martin A, López-Bonet E, Oliveras-Ferraros C, Pérez-Martínez MC, Bernadó L and Menendez JA: Mitotic kinase dynamics of the active form of AMPK (phospho-AMPK alphaThr172) in human cancer cells. Cell Cycle 8: 788-791, 2009. 